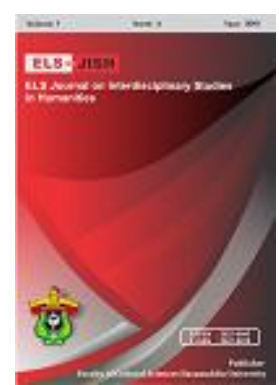

ELS-JISH

ELS Journal on Interdisciplinary Studies on Humanities

Volume 1 Issue 3, 2018

ISSN (print) : 2621-0843

ISSN (online) : 2621-0835

Homepage : http://journal.unhas.ac.id/index.php/jish

\title{
Self-Assessment: Its Roles for Higher Education Students in Academic Writing Class
}

\author{
Cahyaning Fristiara ${ }^{1}$, Sumardi ${ }^{2}$, Nur Arifah Drajati $^{3}$ \\ tiarafristie@student.uns.ac.id $^{1}$
}

\begin{abstract}
Self-Assessment is one kind of assessment technique that used by the teacher and conducted by the students in making grade of learning. By using this kind of assessment, students are stimulated to find strength and weakness in learning process, to assess the understanding about material given by the lecturer, and to judge the achievement in Academic writing class. This paper aimed to investigate the roles of self-assessment in Academic Writing Class. Purposive sampling used as sampling technique, where 5 students in Academic Writing Class involved as research sample. Self-assessment questionnaire applied in this research to know the roles of self-assessment in Academic Writing class. Interview also conducted in collecting some additional information regarding the student difficulties in conducting self-assessment. The result of the study showed that the use of self-assessment in Academic Writing class is important to know students strength and weakness in teaching and learning process, to increase the motivation in writing, and to improve the writing performance. This research expected to give contributions in the educational development especially encourages student's awareness to optimize the use of self-assessment in Academic Writing Class and as consideration for the teachers in conducting assessment process in the teaching and learning activity.
\end{abstract}

Keywords: Self-assessment, Roles, Higher Education Students, Academic Writing Class.

How to cite: : Fristiara, et al. (2018). Self-Assessment: Its Roles for Higher Education Student in Academic Writing Class. ELS Journal on Interdisciplinary Studies in Humanities, 1 (3), 357-365.

\section{Introduction}

Knowing and measuring the ability of the student in joining the class is one of the important processes in teaching and learning activity. The need of the teacher and the student to know the achievement in teaching and learning process encourages many researchers to conduct the research in assessment field. The function of assessment in knowing the ability of the students encourages teachers to find the appropriate assessment to find students strength and weakness. Assessment is one of the important processes, which possible integrated with other English skill. As stated by Hyland (2007) assessment is an integral aspect of the teaching-learning process and central to students' progress toward increasing their writing. In writing activity, the need of conducting assessment for the writing process, help the writer to find the strength and the weakness of product writing.

\footnotetext{
1,2,3 Universitas Sebelas Maret, Surakarta. 
Assessment is the important part in the process of English teaching and learning, which affects the success of the student in understanding the material. Paris and Paris (2011) argue that teacher needs to know the product and process of learning so that student will discover what is learned, what additional effort is required, and what skills are effective. Assessment is one of the techniques used by the teacher in measuring and knowing student achievement based on the goal of teaching and learning. It means that teacher know the effectiveness of technique has been used and the goal has been expected form student after joining in teaching and learning process. Nunan in Birjandi \& Siyyari (2010) asserts that assessment is the subcomponent of evaluation, which is, consist of the means techniques and procedures for collecting and interpreting information about what learners can do and cannot do.

English language teaching in practice; consist of four big skills that are reading, speaking, listening, and writing. Among those skills, writing has gained much interest recently due to the need of communication from different points and geographical spots of the globe. Hyland (2007), explains that writing is a way to share personal meanings. The people construct their own views on topic. They will share their views on a topic to each other then. A person's views may be different from other people's views. It depends on their belief. Therefore, when constructing their views (ideas), the people have to make it understandable and acceptable. In order to improve students' writing ability, the teacher should know students competencies in writing so the teacher can design appropriate strategies to improve students' writing skill. Khonbi \& Sadegi (2012) assert that since the turn of the century, and in line with the developments in language teaching and learning, in most of which learners are taken as the authorities for their own learning, and as learner autonomy is gaining more importance, the responsibility of learning assessment is also shared among the learners themselves. Self-assessment, that is, the ability to identify strengths and weaknesses and points for improvement in one's own performance, has attracted considerable attention from researchers (Birjandi \& Siyyari, 2010). In its narrowest sense, self-assessment in writing indicates any method or incorporation of any activity that causes writers think about, evaluate and revise their writing (Fahimi \& Rahimi, 2015).

\section{Literature Review}

\subsection{Self-Assessment}

In practice, the need of the student to assess themselves, encourage some researchers to conduct a study in this filed. Self-assessment is one form of alternative assessment, which pursues to make the assessment process more student-centered to better support and maximize the learning-taking place (Weisi \& Karimi, 2012). Selfassessment practices are considered an essential component of formative assessment, the reason being that "the desired goal, evidence about present position, and some understanding of a way to close the gap between the two" must be apprehended by the student in order improve their learning Black and William (in Oscarson, 2009).

Student need to make judgment for the work. Making judgment is a part of life whether the ones made are right or wrong, valid and reliable or not (Heywood, 2000). Students need to be active participants in the learning process rather than passive recipients of information (Chalmers \& Fuller, 1996). It assumed that successful language teaching starts from the perspective and the ability of the learners rather than the teachers, so language learners must be aware that they are the most important element in the 
learning process. Consequently, teachers should be able to facilitate learners with the opportunities to develop their self-awareness of their needs, goals, and learning process. Brown and Harris (2013) point out that self-assessment practice can be grouped into three major types: self-ratings, self-estimates of performance on formal assessments, and criteria or rubric-based assessments. In addition, Boekarts (1991) asserts that selfassessment is a form of appraisal that involves a comparison between one's behavioral outcomes and internal and external standard. In higher education, the significance chance from teacher-centered to the learner-centered classroom has forced the teacher to help learners take charge of their own learning.

It can be assumed that self-assessment is defined as 'the involvement of learners in making judgments about their achievements and the outcomes of their learning' and is a valuable approach to support student learning, particularly when used formative. Selfassessment is one of the most important skills which support students' learning and require the students for future professional development and life-long learning, as it develops student capacity to be assessors of learning.

\subsection{Self-Assessment in Writing}

Harmer (2004) states that students should pay attention not only in what to write but also in how to write. Writing is more than to write. There are actually several strategies to write well. In order to improve students' writing ability, the teacher should know students competencies in writing so the teacher can design appropriate strategies to improve students' writing skill. Self-assessment, that is, the ability to identify strengths and weaknesses and points for improvement in one's own performance, has attracted considerable attention from researchers. In its narrowest sense, self-assessment in writing indicates any method or incorporation of any activity that causes writers think about, evaluate and revise their writing (Fahimi \& Rahimi, 2015). The prove about the importance of self-assessment from many researchers, has been encourage many student to conducted this assessment in many aspect.

In the literature, some kinds of researches on self-assessment have been carried out in higher education. One of the reasons is because adult learners are not in the process of acquisition like those of young learners so that they believed to have the ability in knowing the framework for self-monitoring their own learning. Furthermore, adults are among others who are successful when learning without guidance (Brown, 2004).

The concern for involving students to develop their own responsibility towards their learning progress has gained some scholars' interests in implementing self-assessment in the class. Harris and McCann (2008) emphasize that self-assessment is an integral part of learning which provides the teachers with useful information about students' expectations, needs, problems, and worries. When introducing self-assessment in academic writing to students in the University of Arab Emirat, Litz (2009) found that the students are capable of accurately assessing themselves on a finished writing task. In addition, self-assessment is helpful in assisting students to master English writing convention and improve their overall ability.

To investigate whether self-assessment gives impact on Iranian EFL learners' writing skill, Javaherbakhsh (2010) administered the self-assessment techniques to the experimental group. The result show that the implementation of self-assessment in the experimental group improves students writing skill. When Lam (2010) implemented selfassessment towards the end of the semester in the writing class, the students were 
enthusiastic. In addition, he discovered that the students felt motivated to improve their writing. In Birjandi and Siyyari study (2010), it is reported that self-assessment can significantly improve the writing performance of learners in comparison to the learners who were not given the opportunity to assess their own performance.

Based on the research was conducted by many researchers above, shows that selfassessment gives the impact in the writing skill. It can be seen from the aspect of increasing the motivation in writing, improve the writing performance and writing skill. The researcher combined all aspects that had been done by the previous researchers, not only investigate the students' difficulties but also the impact of conducting self-assessment in the Academic Writing class, also involved in this research about the roles of selfassessment in Academic Writing class.

\subsection{The Role of Self-Assessment in Academic Writing Class}

As stated by Oscarson (1989), the rationale of self-assessment in language learning is to promote learning, as it requires students to exercise a variety of learning strategies and higher order thinking skills. He further argues that when doing self-assessment, students raise their level of awareness. It means that they know what their abilities are, how much progress they are making and what they can (or cannot) do with the skills they have acquired. Then, they can engage actively to improve their goal orientation. This continuous assessment technique can help students realize that they do not have to depend entirely on the teacher's opinion. In general, self-assessment support student learning and is one of the most important skills that students require for future professional development and life-long learning, as it develops the capacity to be assessors of learning (Taras, 2010). Taras also points out that self-assessment starts from the perspective of the integration of teaching and learning. It has the opposed meaning with the view that learners and tutors are separate and have discrete roles and distinct areas of focus. Pragmatically, self-assessment helps the lecture in conducting the assessment. In practice, when the primary assessment task is the responsibility of the students, lecture becomes a facilitator and moderator of that process of assessment, in collaboration with the student.

\section{Research Methodology}

\subsection{Research Design}

In this occasion, the research design is qualitative research, which is focused on case study. According to Bassey (1999), educational case study is as a prime strategy for developing educational theory, which illuminates educational policy and enhances educational practice. While Yin (2003) states that a case study is an empirical inquiry that investigates a contemporary phenomenon and context which are not clearly evident.

There are three educational case study types in nowadays. They are (1) theoryseeking and theory-testing case studies, (2) story-telling and picture-drawing case studies, (3) evaluative case studies Bassey (1999). The chosen type of the present case study that can be conceived is evaluative case studies because this research focused on the roles of self-assessment, which is conducted in Academic Writing class.

This research applied qualitative descriptive method using purposive sampling technique. The five students were involved in this study as the respondent regarding the roles of self-assessment in the Academic Writing class. This study aimed to investigate the role of self-assessment and the difficulties by the student when conducting self- 
assessment in Academic Writing class. Self-assessment questionnaire was given to the respondents to know the roles of self-assessment. In addition to get the more information, the researchers also interview the respondents in order to know the difficulties faced by them in conducting self-assessment in Academic Writing class.

\subsection{Data Analysis}

The next method in conducting the research was analyzing data. It was absolutely important to find the result of the research whether or not the research has come to accurate findings. Maykut and Morehouse (in Ary, 2002) state that "data analysis is the heart of qualitative research". That means analyzing data becomes the main part of the research before it becomes the final findings of the study. In order to know the roles of self-assessment in Academic Writing class, the researcher used data analysis based on Miles and Huberman model (1994), which were described in details to take the data. The steps of analyzing qualitative data consist of (1) data reduction, (2) data display, (3) conclusion. After the researchers gave the self-assessment questionnaire to the five respondents in getting the information about the roles of self-assessment, interview used to get some additional information and in -depth analysis for every respondent about their difficulties in the implementation of self-assessment. In this section, the researchers describe the data analysis one by one in detail.

\section{Findings}

After giving self-assessment questionnaire, responden1 argued that the use of selfassessment motivated her writing ability, developed the awareness of her writing ability, and helped to develop the content of writing. The use of self-assessment stimulates her evaluative point of view about how was her learning ways in Academic Writing class. Selfassessment in Academic Writing class adds her knowledge of the purpose of learning through learning reflection. The involvement of the student in the process of assessment, helped to develop the knowledge about how was the process of self-assessment in Academic Writing class. She argued that by using self-assessment, it helped her in knowing the error of punctuation, the error in using spelling, the process in generating ideas and the ways to revise her writing, but she does not agree that grammar error would be identified by using the self-assessment.

To get additional information about students difficulties in conducting selfassessment, the researcher conducted interview to five respondent and get the information that some students feel reluctant to assess their own work and lack of confident to judge their own work. The students prefer to be assessed by an expert rather than them-selves. The paradigm about assessing work is lecturer responsibility. Afraid of being wrong when assessing them-selves is the other factors. The unlike factor of using self-assessment, add the difficulties of the students in conducting self-assessment. According to Leach (2012), some indicators that indicate the difficulties faced by the students in conducting self-assessment are reluctant, unconfident, uncomfortable, afraid, unlike, and prefer to assess by others.

\section{Disscussion}

\subsection{Self-assessment promotes learning}

It gives learners training in evaluation, which has beneficial consequences for language learning. After giving self-assessment questionnaire, respondents argued that the use of self-assessment motivated her writing ability, developed the awareness of her 
writing ability, and helped to develop the content of writing. The use of self-assessment stimulates her evaluative point of view about how was her learning ways in Academic Writing class. Self-assessment in Academic Writing class adds her knowledge of the purpose of learning through learning reflection. The involvement of the student in the process of assessment, helped to develop the knowledge about how was the process of self-assessment in Academic Writing class. She argued that by using self-assessment, it helped her to know the error of punctuation, know the error in using spelling, help in generating ideas, know the grammar mistake and stimulate in revising her writing.

\subsection{Raises the awareness of both students and teacher or perceived levels of abilities}

Through self-assessment, learners are encouraged to look at course content more carefully, and develop evaluative attitudes toward what and how they learn. After giving self-assessment questionnaire, respondents argued that the use of self-assessment motivated her writing ability, developed the awareness of her writing ability, and helped to develop the content of writing. The use of self-assessment stimulates her evaluative point of view about how was her learning ways in Academic Writing class. Self-assessment in Academic Writing class adds her knowledge of the purpose of learning through learning reflection. The involvement of the student in the process of assessment, helped to develop the knowledge about how was the process of self-assessment in Academic Writing class. She argued that by using self-assessment, it helped her in knowing the error of punctuation, the error in using spelling, the process in generating ideas and the ways to revise her writing, but she does not agree that grammar error would be identified by using the self-assessment.

\subsection{Self-assessment is highly motivating with regard to goal-orientation}

Learners gain knowledge of learning goals through reflection. After giving selfassessment questionnaire, respondents argued that the use of self-assessment motivated her writing ability, developed the awareness of her writing ability, and helped to develop the content of writing. The use of self-assessment stimulates her evaluative point of view about how was her learning ways in Academic Writing class. Self-assessment in Academic Writing class adds her knowledge of the purpose of learning through learning reflection. The involvement of the student in the process of assessment, helped to develop the knowledge about how was the process of self-assessment in Academic Writing class. She argued that by using self-assessment, it helped her to know the error of punctuation, know

the error in using spelling, help in generating ideas, know the grammar mistake and stimulate in revising her writing.

\subsection{The involvement of learners in the assessment process results in the learners' boarder perspective within the area of assessment.}

In the interview process, the respondents told that the use of self-assessment motivate them to achieve the goal of learning. For example, by using self-assessment, the student can know the weakness faced by them in learning process. After knowing the weakness, the students will try to improve the indicator, which is affecting the weakness.

Based on the result of interview, some respondents argued that the involvement of them in the assessment process will encouraged them to understand the concept of assessment technique used. When the student involves in the process of assessment, 
automatically they encourage understanding the purpose of assessment technique used and the procedure of the use of assessment.

\subsection{By prcaticing self-assessment students take ap part in their own evaluation, sharing the burden of assessment with their teacher.}

From the interview process, respondents assumed that when conducting selfassessment they have the chance to judge their learning way. Involving students in the assessment process, encouraged them to know the concept of assessment technique used. After that understand the concept of assessment, the student can discuss with the lecture about the next process of assessment. From the result of interview, many students argued that by practicing self-assessment, help them in revising their writing and generating ideas when starting the writing process.

\section{Conclusion}

The techniques of self-assessment and evaluation play important role in evaluating the effectiveness of individual learning, enhancing their motivation, and training learners for life-long learning. Learners need to assess their progress in order to plan their future learning. The teacher can used the result of assessment as the feedback for the next teaching activity. It seems that self-assessment can not only raise the students' selfawareness about their meta-cognitive conditions, but also can promote their motivation and ability.

Based on the researches conducted by some researchers above found that selfassessment in the assessment of writing is likely to foster growth in student writing ability and transfer to future writing tasks. It can be seen from the aspect of increasing the motivation in writing, and improving the writing performance. It can be conclude that the implementation of self-assessment in writing class is important. By knowing the difficulty faced by the student in conducting self-assessment in the writing class, it will develop student awareness to optimize the use of self-assessment in assessing their self and the result of the assessment will be more accurate.

The need for the students in assessing their learning progress is in relation to the need of teacher in giving feedback of the students learning achievement. The use of selfassessment help teacher in the process of giving feedback. By knowing the strength and the weakness of the student in the teaching and learning process, the teacher will find what technique must be done and what strategies can be used in the next meeting of the class. Even, the focus of self-assessment is focused in student self, but the benefit of the use of this kind of assessment can be used by the English teacher, English lecturer, tutor or someone, which is involved in the teaching and learning process, to support the process of assessment.

\section{References}

Ary, D., Jacobs, L.C., \& Sorensen, C. (2010). Introduction to Research Education. USA: Wadsworth.

Bassey, M. (1999). Case study research in educational settings. Buckingham [England: Open University Press.

Birjandi, P., \& Siyyari,, M. (2010). Self-assessment and peer-assessment: A comparative study of their effect on writing performance and rating accuracy. Iranian Journal of Applied Linguistics, 13(1), 23-45. 
Boekaerts, M. (1991). Subjective competence, appraisals and self-assessment. Learning and Instruction. 1(1), pp. 1-17. doi: http://dx.doi.org/10.1016/0959-4752(91)90016-2

Brown, H.D. (2004). Language Assessment: Principles and Classroom Practices. New York: Pearson Education.

Brown, G. T. L., \& Harris, L. R. (2013). Student self-assessment. In J. H. McMillan (Ed.). The SAGE handbook of research on classroom assessment (pp. 367-393). Thousand Oaks, CA: Sage.

Chalmers, D \& Fuller, R. (1996). Teaching for learning at University. London: Kogan Page.

Fahimi, Z., \& Rahimi, A. (2015). The Effcet of Self-assessment Practice on Writing Skill. Journal of Social and Behavioral Sciences, 192(2015), 730-736. doi: www.sciencedirect.com

Harmer, J. 2004. How to Teach Writing. Essex: Pearson Education Ltd.

Harris, M., \& McCann, P. (2008). Assessment. Oxford: Heinemann.

Heywood, J. (2000). Assessment in Higher Education (Student Learning, Teaching, Programmes, and Institution). United States: Jessica Kingsley Publisher Ltd.

Hyland, K. (2007). Genre and Second Language Writing. USA: The University of Michigan Press.

Javaberbakhsh, M. (2010). The impact of self-assessment on Iranian EFL learners' writing skill. English Language Teaching, 3(2), 213-218. doi: https://pdfs.semanticscholar.org/0045/0c7be8802b66a16462f48606cb83759aed3e.p df

Khobi, Z. A., \& Sadeghi, K. (2012). The Effect of Assessment Type (Self vs. Peer) on Iranian University EFL Students' Course Achievement. Journal of Social and Behavioral Sciences, 70(2013), 1552-1564. doi:10.1016/j.sbspro.2013.01.223

Lam, R. (2010). The role of self-assessment in students' writing portfolios: A classroom investigation. TESL Reporter, 43(2), 16-34. doi: https://www.google.com/url?sa=t\&rct=j\&q=\&esrc=s\&source=web\&cd=1\&ved=2ahUK EwjKidbWspHdAhXCrY8KHSqMC54QFjAAegQIAhAC\&url=http\%3A\%2F\%2Fcsimmo nds.pbworks.com\%2Fw\%2Ffile\%2Ffetch\%2F118283802\%2FThe\%2520Role\%2520 of\%2520Self-

Assessment\%2520in\%2520Students\%2520Writing\%2520Portfolios\%2520A\%2520Cl assroom\%2520Investigation.pdf\&usg=AOvVaw12JKZmBcXL8xe3o0MHHxuA

Leach, L. (2012). Optional self-assessment: some tensions and dilemmas, Assessment \& Evaluation in Higher Education, 37:2, 137-147.

Litz, D. (2009). Self-assessment in academic writing: A UEA case study. Learning and teaching in higher education: Gulf Perspectives, 6(2), 1-16.

Miles, M. B., \& Huberman, A. A. (1994). Qualitative Data Analysis (2nd Ed.). Thousand Oaks: Sage Publications Inc.

Weisi, H., \& Karimi, M. N. (2012). The Effect of Self-Assessmnet among Iranian EFL Learners. Journal of Social and Behavioral Sciences, 70(2013), 731-737. doi:10.1016/j.sbspro.2013.01.117 
Oscarson, A. D. (2009). Self-Assessment of Writing in Learning English as a Foreign Langauge. Sweden: Acta Universitatis Gothoburgensis.

Oscarson, M. (1989). Self-assessment of language proficiency: rationale and implications. Language Testing, 6(1), 1-13.

Paris, S. G., \& Paris, A. H. (2001). Classroom applications of research on self-regulated learning. Educational Psychologist, 36(2), 89-101.

Taras, M. (2010). Student self-assessment: processes and consequences. Teaching in Higher Education, 15(2), 199-209.

Yin, R. K. (2003). Case Study Research. New Delhi: Thousand Oaks. 